\title{
Impact of conventional sterilization and ohmic heating on the amino acid profile in vegetable baby foods
}

\author{
M. Mesías', M. Wagner², S. George², F. J. Morales' \\ 'Institute of Food Science, Technology and Nutrition, ICTAN-CSIC, 28040 Madrid, Spain \\ ${ }^{2}$ Centre Technique de la Conservation et des Produits Agricoles (CTCPA), Site Agroparc, F-849II \\ Avignon Cedex 9, France
}

\begin{abstract}
Loss of nutrients during processing of baby foods should be minimized to maintain the nutritional quality and therefore to support a satisfactory nutritional status in infants. The present study aimed to evaluate the advantages of the ohmic heating versus conventional retort sterilization on the maintenance of the amino acid content and protein quality of sterilized vegetable baby foods. Results revealed that total protein content was not affected after both sterilization methods. However, after retort sterilization the content of total essential and nonessential amino acids significantly decreased in $35 \%$ and $9 \%$, respectively, thus decreasing the quality protein. Contrarily, ohmic heating did not have effect on the total amino acid content and, therefore, this alternative process did not modify the protein quality of the sample. In conclusion, ohmic treatment may be successfully applied as an alternative method to conventional sterilization to maintain the nutritional quality of protein in vegetable baby foods.
\end{abstract}

Industrial relevance: Ohmic heating is an emerging technology which applies an electric current to the food, promoting uniform and rapid heating in the product. This fact facilitates the destruction of microorganisms in a shorter period of time and reduces the possible losses of labile nutrients caused with the conventional thermal treatments such as pasteurization or sterilization. The purpose of the present study was to evaluate the effect of conventional retort sterilization and alternative sterilization by ohmic heating on the amino acid content and protein quality of vegetable baby foods. These findings could be used for the baby food industries in order to improve nutritional quality of these products after heating processes.

KEYWORDS: Baby foods, protein, amino acids, retort sterilization, ohmic heating.

\section{INTRODUCTION}

Thermal treatment is employed in food processing in order to preserve the product, extends its shelflife and ensures consumer safety. Conventional treatments such as pasteurization or sterilization are associated with the application of high-temperature for an extended period of time, thus guaranteeing an appropriate destruction of the microorganisms. However product quality can be deteriorated resulting in undesirable sensorial and nutritional changes and specifically in losses of heat-sensitive nutrients (Awuah, Ramaswamy, \& Economides, 2007).

Over the past few years some emerging technologies have been researched with the aim of improving traditional thermal processing characteristics. Among them ohmic heating provides advantages over the conventional classic retort sterilization, since the electrical current applied increases the temperature rapidly and uniformly for both homogeneous and heterogeneous products allowing a controllable heating rate and the monitorization of energy inputs online (Sastry, Heskitt, Sarang, Somavat, \& Ayotte, 2014). This rapid application facilitates the destruction of microorganisms in a shorter period of time, thus reducing the negative effects on the sensory properties and losses of labile nutrients (Akdemir Evrendilek, Baysal, Icier, Yildiz, Demirdoven, \& Bozkurt, 20I2) and, in turn, reduces the maintenance costs. However, the electrical conductivity of foods and the excess costs of commercial ohmic heating can limit the application of this alternative method (Ramaswamy, Marcotte, Sastry, \& Abdelrahim, 2014). 
Thermal treatments applied to infant foods are critically important to guarantee microbiological safety. However, loss of nutrients linked to heating processes must be avoided to maintain the nutritional properties. Since baby purees together with infant formulas or breast milk are the only food sources for babies, it is very important that this type of food has an adequate nutritional quality to support a satisfactory nutritional status and a normal growth rate (Hernández Rodríguez, 200I). Due to the advantages linked with ohmic heating, it might be an alternative heating method to achieve the sterilization of baby products.

Conductivity of fruits and vegetables allows ohmic heating to be implemented as a sterilization method of these products. Ohmic heating has been tested in the treatment of artichoke heads (Guida, Ferrari, Pataro, Chambery, Di Maro, \& Parente, 2013), carrots (Lemmens et al., 2009), cauliflower (EliotGodéreaux, Zuber, \& Goullieux, 200I) papaya pulp (Gomathy, Thangavel, Balakrishnan, \& Kasthuri, 20I5) and fruit desserts (Castro, Teixeira, Salengke, Sastry, \& Vicente, 2004; Pereira, Pereira, Teixeira, \& Vicente, 2006; Louarme \& Billaud, 2012) and the effects on nutritional parameters have been comparedwith those showed after the application of conventional treatments. These studies are mainly focused on the evaluation of the stability or degradation of sugars, ascorbic acid, carotenoids or polyphenols. However, to our knowledge little is known about the effect of ohmic method on protein and amino acid profile in a food product and specifically in infant foods. The composition of amino acids in a food can be used as a measure of its nutritive value since it is the factor determining the quality of protein (Levesque, Elango, \& Ball, 20I2). In the present study the amino acid profile of vegetable baby purees before sterilization (control samples) and after retort sterilization (as conventional treatment) and ohmic heating (as alternative treatment) was evaluated. The aim was to investigate the feasibility of the ohmic treatment to provide vegetable purees with an enhanced amino acid profile as compared with conventional sterilization.

\section{MATERIALS AND METHODS}

\section{Reagents and chemicals}

Ethylenediaminetetraacetic acid (EDTA), ninhydrine, norleucine and amino acid standards were purchased from Sigma (St Louis, MO, USA). Chloroform, methanol and hydrochloric acid were supplied from Panreac (Barcelona, Spain). The Milli-Q water used was produced using an Elix3 water purification system coupled to an Advantage I0 Milli-Q module (Millipore, Molsheim, France). All other chemicals and reagents were of analytical grade.

\section{Vegetable baby puree manufacture}

Vegetable baby purees were prepared at semi-industrial scale by the Centre Technique de la Conservation et des Produits Agricoles (CTCPA) in Avignon (France). The recipe of purees was as follows: $40 \%$ carrots, $20 \%$ peas, $15 \%$ zucchini, $0.1 \%$ salt and $24.9 \%$ water. Frozen vegetables were directly provided by a large international company dedicated to baby foods. Vegetables were mixed and precooked through boiling water for $10 \mathrm{~min}$ at $90^{\circ} \mathrm{C}$, then were crushed with a colloidal grinder to make a smooth puree, which was reheated to $85^{\circ} \mathrm{C}$ with stirring. Afterwards the puree was divided into three aliquots. One of the aliquots was kept as a control sample (puree without sterilization), a second aliquot was retort sterilized (conventional treatment) and the remaining aliquot was treated by ohmic heating (alternative treatment). For the conventional retort sterilization, the purees were placed in jars and sterilized by the classic static retort system (Lagarde multiprocess, France), spraying hot water on the jars at $129^{\circ} \mathrm{C}(\mathrm{Fo}=10 \mathrm{~min})$. For the alternative process the purees were sterilized by ohmic heating system (SIMACO, Italy) which consisted of a static ohmic heater made of a cylindrical polycarbonate tube. Stainless steel electrodes were installed at both ends of the tube and alternatively connected to the ground potential and the $25 \mathrm{kHz}$ high voltage from the regular $50 \mathrm{~Hz}$ network. The tube was cooled and the product was heated in the center, in the whole volume, at $129^{\circ} \mathrm{C}$ and $350 \mathrm{~L} / \mathrm{h}$ (Fo $=11 \mathrm{~min}$ ) and 
aseptically filled in pouches. Both procedures were performed twice and four samples of control and sterilized purees were taken for analyses. Samples were homogenized with a hand blender (Vital CM; Taurus, Barcelona, Spain), lyophilized and stored at $4^{\circ} \mathrm{C}$ until analysis. The proportion of water lost during lyophilization was taken into account for the expression of the results as fresh matter.

\section{Determination of total protein content}

Total protein content was determined in the samples using an automated nitrogen analyzer (FP-2000; Dumas Leco Corp., St. Joseph, MI), after calibration of the instrument with EDTA. The nitrogen-toprotein conversion factor was $\mathrm{N} \times 6.25$. Analysis was performed in triplicate. The results were expressed as $\mathrm{g}$ of protein $/ 100 \mathrm{~g}$ of product (fresh matter).

\section{Determination of total and free amino acids}

Free amino acids were extracted from the lyophilized samples with water:chloroform:methanol (3:5:12, $\mathrm{v} / \mathrm{v}$ ) following the method reported by Hacham, Avraham and Amir (2002). For total amino acids determination, samples were hydrolyzed using $6 \mathrm{~N} \mathrm{HCl}$ containing phenol for $21 \mathrm{~h}$ at $110^{\circ} \mathrm{C}$ prior to chromatographic separation. Total and free amino acids were determined according to Spackman, Stein and Moore (1958). Analyses were conducted with a Biochrom 30 series amino acid analyzer (Biochrom Ltd., Cambridge Science Park, UK) using a Na-cation exchange column $(20 \times 0.46 \mathrm{~cm}$ i.d.). Amino acids were post-columnderivatizedwith ninhydrin reagent and detected by absorbance at $440 \mathrm{~nm}$ (proline) and $570 \mathrm{~nm}$ (all the other amino acids). A standards amino acid mixture (Sigma Chemical Co.) was used for the calibration and norleucine was used as an internal standard.

Results were expressed in $\mathrm{mg} / \mathrm{l} 00 \mathrm{~g}$ of fresh sample. The composition of the amino acids in $\mathrm{mg} / \mathrm{l} 00 \mathrm{~g}$ protein was compared with the FAO pattern (FAO, 2013) in order to estimate the quality of the protein. The amino acid score index was calculated comparing the content of the essential amino acid in the protein with its content in the requirement pattern for the different age groups. An essential amino acid showing a score less than I was a limiting amino acid. The essential amino acid index (EAAI)was calculated by using the ratio of amino acid in test protein to the amino acid in the reference protein according the equation proposed by Steinke, Prescher and Hopkins (1980).

\section{Statistical analysis}

Statistical analyses were performed using the Statgraphics Centurion XV statistical program (Herndon, $V A$ ). Data were expressed as the mean value \pm SD. Analysis of variance (ANOVA) and the Duncan test were applied to determine differences between means. Differences were considered to be significant at $\mathrm{P}<0.05$.

\section{RESULTS AND DISCUSSION}

Total protein content was $1.8 \mathrm{~g} / 100 \mathrm{~g}$ in the three baby foods, without significant differences in the samples before and after the different sterilization treatments. Data are expressed for fresh matter taking into account the water content of the baby purees (89-91\%) in order to provide a more realistic approximation about the composition of the baby food for consumption. Protein content was in line with that which was expected according to the ingredients of the purees and the Table of Food Composition (Moreiras-Tunio, Carbajal, Cabrera-Forneiro, Cuadrado-Vives, 2013). Considering an average weight of $200 \mathrm{~g}$ for a vegetable baby food sample, it would provide around $27-33 \%$ of the recommended daily protein intake for children aged 6 months-3 years (National Research Council, 2005).

Seventeen amino acids were quantified in the vegetable baby food samples. During analyses asparagine and glutamine can be quantitatively converted into aspartic and glutamic acid, therefore these amino acids were determined together and encoded as Asx (aspartic acid + asparagine) and Glx (glutamic acid 
+ glutamine). Tryptophan was not quantified due to its loss during the analysis and digestion of the samples. Amino acid profile was similar for unsterilized samples (control), retort and ohmic treated samples and for both free and total amino acids. Results for free and total amino acids content are shown in Table I and Table 2. Among free amino acids, arginine was the most abundant amino acid, followed by alanine, glutamic acid + glutamine and glycine. In contrast, the less abundant amino acids were firstly cysteine with methionine (total sulphur amino acid) and secondly glycine (Table I). For total amino acids, glutamic+glutamine were the majority whereas tyrosine and total sulphur amino acids were the limiting amino acids (Table 2). Free amino acids values accounted for $18 \%, 21 \%$ and $15 \%$ of the total amino acids quantified in the vegetable baby food samples in unsterilized samples and after retort and ohmic sterilization, respectively.

According to Pompei et al. (1988) during heating protein can react with different components of the food leading to alterations in amino acids content because of $(I)$ interactions between amino acids causing new links and reducing the bioavailability; (2) degradation reactions of side chains; (3) modifications of amino acids with SH- and S-S groups; (4) denaturing; (5) interactions with lipids, which can decrease the availability of sulphur-containing amino acids and (6) interactions with carbohydrates (Maillard reaction), where lysine is the most affected amino acid due to its double amino group. From these alterations, Maillard reaction has been suggested to be the primarily cause for the loss in nutritional value of food proteins during heat processing (Sohn \& Ho, 1995). Changes in the amino acids profile depend on the structural composition and the susceptibility to heat treatment (Jovanović, Barać, \& Maćej, 2005). In the present study, both free and total amino acids showed significant differences ( $\mathrm{b}$ 0.05 ) after conventional and ohmic heating when compared with unsterilized samples, although the total protein content was not affected by the different treatments.

The total content of free amino acids detected in control purees $(2 / 3 \mathrm{mg} / 100 \mathrm{~g})$ was significantly reduced by up to $5.6 \%$ after retort sterilization $(201 \mathrm{mg} / 100 \mathrm{~g})$ and $17.8 \%$ after ohmic heating (I75mg/l00 g) (Table I). Higher losses of free amino acids (22.6\%) were observed by Yeung, Lee, Lin, Yang, Huang and Chuang (2006) when infant formulas were subjected to pasteurization or by Zhang, $\mathrm{Hu}$, Chen and $\mathrm{Ye}(20 \mathrm{II})$ in bamboo shoots after boiling and stir-frying, where free amino acids decreased by $38 \%$ and 34\%, respectively. Garde-Cerdán, Arias-Gil, Marselles-Fontanet, Ancín-Azpilicueta and Martín-Belloso (2007), on the contrary, argued that neither thermal nor electric treatments modified the free amino acids content of grape juices. In the samples of vegetable purees most of the free amino acids were significantly reduced after ohmic heating, whereas conventional treatment only affected six of the seventeen amino acids. Phenylalanine was the most affected by the two treatments, with the $22 \%$ decrease in retort sterilization and $42 \%$ in ohmic heating. The next most affected amino acid was histidine, with decreases of $13 \%$ and $31 \%$, respectively. Arginine, serine and the mix of glutamic acid + glutamine also showed decreases after sterilization. In this case reductions were lower than $12 \%$ except for arginine and Glx after ohmic heating, which exhibited losses higher than $20 \%$. In contrast, proline, glycine, methionine and cysteine did not display significant differences among the unsterilized and sterilized samples. The rest of the amino acids were reduced only after ohmic treatment, showing losses close to $30 \%$ for tyrosine and lower than $20 \%$ for the others.

Regarding the total content of amino acids, it significantly decreased by $20 \%$ in baby foods subjected to retort sterilization (Table 2) as compared with unsterilized samples. This sterilization method affected all the amino acids except alanine, tyrosine and cysteine. The highest losses were produced in isoleucine (5I\%), leucine, valine and phenylalanine (39\%), and methionine $(31 \%)$ followed by lysine $(29 \%)$ and threonine and histidine (25\%). Lower losses were found in glycine and the mix glutamic acid + glutamine and aspartic acid + asparagine, with values close to $9 \%$. Several studies have shown that total amino acid content can be affected by cooking conditions. Decreases of $12 \%$ and $24 \%$ were reported by Korus (2012) in blanched and cooked kale leave samples compared with raw leaves and Lisiewska, Slupski, 
Skoczen-Slupska and Kmiecik (2009) found that amino acid content in cooked Brussels sprouts was 89$108 \%$ of that observed in the raw material. Similarly, the content in green asparagus decreased after blanching and canning, phenylalanine, tyrosine, methionine and valine being the most stable constituents during the treatments (López, Ros, Rincón, Ortufio, Periago, \& Martinez, 1996).

Contrary to results on retorting, total amino acids was not affected by ohmic heating in our experiment, with the exception of the arginine content, whose concentration decreased by 13\% compared with the control samples. From these findings it may be suggested that the sterilization with electrical method versus retort sterilization is a convenient method to maintain the total amino acids profile in vegetable baby purees. No effects or even increase in amino acid content have also been exhibited in green cauliflower (with the exception of tyrosine) (Slupski, Lisiewska, Kmiecik, Gebcznski, \& Sobczynska, 20I0a) and in spinach (with the exception of cistine and methionine) (Slupski, Achrem-Achremowicz, Lisiewska, \& Korus, 20 IOb) after culinary process as compared with the composition in raw samples.

Based on their biological value from a nutritional point of view, amino acids were grouped as essential and non-essential amino acids. In the case of free amino acids, both essential and non-essential amino acids were affected by ohmic heating, decreasing by up to $17 \%$ and $18 \%$, respectively (Fig. Ia). Retort sterilization only reduced the content of non-essential amino acids $(\sim 8 \%)$ whereas essential amino acids were not affected by this treatment. Contrary results were observed in total amino acids content since ohmic heating did not cause significant changes whereas losses of $36 \%$ and $10 \%$ were exhibited in essential and non-essential amino acids, respectively, after retort sterilization (Fig. Ib). Controversial results on the content of essential or nonessential amino acid in relation to the thermal treatment of foods have been published previously. Losses of $27-28 \%$ have been observed in both essential and nonessential amino acids in infant formulas subjected to autoclave and conventional preparations (Yeung et al., 2006) and between 48 and $67 \%$ and 9 and 34\% in essential and non-essential amino acids, respectively, in samples of broccoli after sterilization (Murcia et al., 200I). On the contrary, the application of technological treatments such as soaking, microwave and $\mathrm{y}$-irradiation had little impact on the profiles of essential amino acids except cysteine in velvet bean (Gurumoorthi, Janardhanan, \& Myhrman, 2008). As the main determinant of food protein quality is the content and availability of essential amino acids, it can be deduced that food protein quality and therefore, the nutritive value of vegetable baby purees ohmically heated is similar to unsterilized baby purees and better than samples conventionally sterilized by retort treatment.

Table 3 shows the amino acid score index and essential amino acid index (EAAl) of the baby food samples according to the requirements for different age groups (FAO, 20I3). Even though these samples are mainly designed for infants, other age groups can also consume them and, therefore, requirements for a wide range of population have been taken into account for the estimations. Results showed that Sulphur amino acids were the limiting amino acids in all the samples (unsterilized and sterilized by retort and ohmic heating), with a score varying from 3 to 22 (Table 3). Similar results have been obtained in other investigations (Diasolua Ngudi, Kuo, \& Lambein, 2003; Slupski et al., 2010a, b). Besides sulphur amino acids, histidine and aromatic acids were the second order limiting group in the vegetable baby foods. After retort sterilization the score indexes were lower than those in unsterilized baby foods whereas ohmic heating did not modify these parameters. Regarding the global essential amino acid index, values ranged from 70 to 85 in unsterilized samples for the different age groups and therefore it may be assumed that protein in vegetable baby purees supplies sufficient quantities of the most essential amino acids required by humans. These values were similar for samples treated with ohmic heating but they decreased by $37 \%$ after retort sterilization. These results emphasize the importance of the choice of heating process to maintain the nutritional quality of a food product and corroborate that ohmic heating may be an alternative method applied to vegetable baby purees in order to maintain the protein quality. 


\section{CONCLUSIONS}

In the present study, the impact of conventional or ohmic heat processing on the amino acid profile was investigated in vegetable baby foods. Results revealed that neither of the two processes affected the total protein content however, differences were observed in the amino acids profile after treatment. Retorted baby foods contained around $20 \%$ less total amino acids than in unsterilized samples (35\% essential amino acids and $9 \%$ non-essential amino acids). On the contrary, ohmic heating did not decrease total amino acids in the baby puree, maintaining the same content of essential and nonessential amino acids as in unsterilized samples. These findings were likewise observed in the protein quality of the different samples. In conclusion, ohmic heating promotes less nutrient loss than the conventional method in vegetable baby purees maintaining the amino acids profile and therefore the protein quality of the sample before sterilization. Therefore, ohmic treatment may be successfully used as an alternative method to ensure microbiological and nutritional quality of infant foods.

\section{CONFLICT OF INTEREST}

The authors declare that they have no conflict of interest.

\section{ACKNOWLEDGEMENTS}

This research was funded by the grant EU-FP7-265558 PROMETHEUS project. Authors thanks to Mr. G. Guerrero (USTA) for technical assistance with LECO analysis and Protein Chemistry Service from the Biological Research Centre for amino acids analyses.

\section{REFERENCES}

Akdemir Evrendilek, G., Baysal, T., Icier, F., Yildiz, H., Demirdoven, A., \& Bozkurt, H. (2012). Processing of fruits and fruit juices by novel electrotechnologies. Food Engineering Reviews, 4, 68-87.

Awuah, G. B., Ramaswamy, H. S., \& Economides, A. (2007). Thermal processing and quality: Principles and overview. Chemical Engineering and Processing, 46, 584-602.

Castro, I., Teixeira, J. A., Salengke, S., Sastry, S. K., \& Vicente, A. A. (2004). Ohmic heating of strawberry products: Electrical conductivity measurements and ascorbic acid degradation kinetics. Innovative Food Science and Emerging Technologies, 5, 27-36.

Diasolua Ngudi, D., Kuo, Y. H., \& Lambein, F. (2003). Amino acid profiles and protein quality of cooked cassava leaves or 'saka-saka'. Journal of the Science of Food and Agriculture, 83, 529-534.

Eliot-Godéreaux, S. C., Zuber, F., \& Goullieux, A. (2001). Processing and stabilisation of cauliflower by ohmic heating technology. Innovative Food Science \& Emerging Technologies, 2, 279-287.

FAO (2013). Dietary protein quality evaluation in human nutrition. Report of an FAO Expert consultation. FAO Food and Nutrition Paper 92. Rome, Italy: FAO.

Garde-Cerdán, T., Arias-Gil, M., Marselles-Fontanet, A. R., Ancín-Azpilicueta, C., \& Martín-Belloso, O. (2007). Effects of thermal and non-thermal processing treatments on fatty acids and free amino acids of grape juice. Food Control, 18, 473-479.

Gomathy, K., Thangavel, K., Balakrishnan, M., \& Kasthuri, R. (2015). Effect of ohmic heating on the electrical conductivity, biochemical and rheological properties of papaya pulp. Journal of Food Process Engineering, 38, 405-413.

Guida, V., Ferrari, G., Pataro, G., Chambery, A., DiMaro, A., \& Parente, A. (2013). The effects of ohmic and conventional blanching on the nutritional, bioactive compounds and quality parameters of artichoke heads. LWT—Food Science and Technology, 53, 569-579.

Gurumoorthi, P., Janardhanan, K., \& Myhrman, R. V. (2008). Effect of differential processing methods on L-Dopa and protein quality in velvet bean, an underutilized pulse. LWT, 4I, 588-596.

Hacham, Y., Avraham, T., \& Amir, R. (2002). The N-terminal region of arabidopsis cystathioninesynthase plays an important regulatory role in methionine metabolism. Plant Physiology, 128, 454-462.

Hernández Rodríguez, M. (200I). Alimentación infantil. Madrid, Spain: Ediciones Díaz de Santos. 
Jovanović, S., Barać, M., \& Maćej, O. (2005). Whey proteins—properties and possibility of application. Mljekarstvo, 55, 215-233.

Korus, A. (2012). Effect of technological processing and preservation method on amino acid content and protein quality in kale (Brassica oleracea L. var. acephala) leaves. Journal of the Science of Food and Agriculture, 92, 618-625.

Lemmens, L., Tibäck, E., Svelander, C., Smout, C., Ahrné, L., Langton, M., et al. (2009). Thermal pretreatments of carrot pieces using different heating techniques: Effect on quality related aspects. Innovative Food Science and Emerging Technologies, 10, 522-529.

Levesque, C. L., Elango, R., \& Ball, R. O. (20I2). Metabolic availability of amino acids in food proteins: New methodology. In J. P. F. D'Mello (Ed.), Amino acids in human nutrition and health (pp. 256-266). London, UK: CAB International.

Lisiewska, Z., Slupski, J., Skoczen-Slupska, R., \& Kmiecik, W. (2009). Content of amino acids and the quality of protein in Brussels sprouts, both raw and prepared for consumption. International Journal of Refrigeration, 32, 272-278.

López, G., Ros, G., Rincón, F., Ortufio, J., Periago, M. J., \& Martinez, M. C. (1996). Amino acids and in changes in green vitro protein digestibility asparagus (Asparagus oficinalis, L.) during growth and processing. Food Research International, 29, 617-625.

Louarme, L., \& Billaud, C. (20I2). Evaluation of ascorbic acid and sugar degradation products during fruit dessert processing under conventional or ohmic heating treatment. LWT-Food Science and Technology, 49, 184-187.

Moreiras-Tunio, O., Carbajal, A., Cabrera-Forneiro, L., \& Cuadrado-Vives, C. (2013). In O. Moreiras, A. Carbajal, L. Cabrera, \& C. Cuadrado (Eds.), Tablas de composición de alimentos (16th ed.). Madrid, Spain: Ediciones Pirámides.

Murcia, M. A., López-Ayerra, B., Martínez-Tomé, M., \& García-Carmona, F. (200I). Effect of industrial processing on amino acid content of broccoli. Journal of the Science of Food and Agriculture, 8I, 12991305.

National Research Council (2005). Dietary reference intakes for energy, carbohydrate, fiber, fat, fatty acids, cholesterol, protein, and amino acids (macronutrients). Washington, DC: The National Academies Press.

Pereira, R., Pereira, M., Teixeira, J. A., \& Vicente, A. (2006). Effects of ohmic heating technology in chemical properties of foods. 33rd International Conference of SSCHE May 22-26. Slovakia: Tatranské Matliare.

Pompei, C., Rossi, M., \& Maré, F. (1988). Protein quality in commercial milk-based infant formulas. Journal of Food Quality, 10, 375-391.

Ramaswamy, H. S., Marcotte,M., Sastry, S., \& Abdelrahim, K. (2014). Ohmic heating in food. Boca Raton, FL: CRC Press.

Sastry, S. K., Heskitt, B. F., Sarang, S. S., Somavat, R., \& Ayotte, K. (20/4). Why ohmic heating? Advantages, applications, technology, and limitations. In H. S. Ramaswamy, M. Marcotte, S. Sastry, \& K. Abdelrahim (Eds.), Ohmic heating in food (pp. 7-14). Boca Raton, FL: CRC Press.

Slupski, J., Achrem-Achremowicz, J., Lisiewska, Z., \& Korus, A. (20l0b). Effect of processing on the amino acid content of New Zealand spinach (Tetragonia tragonioides Pall. kuntze). International Journal of Food Science and Technology, 45, 1682-1688.

Slupski, J., Lisiewska, Z., Kmiecik,W., Gebcznski, P., \& Sobczynska, L. (2010a). The effect of processing on the amino acid content in green cauliflower. Agricultural and Food Science, 19, 136-143.

Sohn, M., \& Ho, C. T. (1995). Ammonia generation during thermal degradation of amino acids. Journal of Agricultural and Food Chemistry, 43, 300I-3003.

Spackman, D. H., Stein,W. H., \& Moore, S. (1958). Automatic recording apparatus for use in the chromatography of amino acids. Analytical Chemistry, 30, I190-1205.

Steinke, F. H., Prescher, E. E., \& Hopkins, D. T. (1980). Nutritional evaluation (PER) of isolated soybean protein and combinations of food proteins. Journal of the Food Science, 45, 323-327. 
Yeung, C. Y., Lee, H. C., Lin, S. P., Yang, Y. C., Huang, F. Y., \& Chuang, C. K. (2006). Negative effect of heat sterilization on the free amino acid concentrations in infant formula. European Journal of Clinical Nutrition, 60, I36-|4I.

Zhang, J. J., Hu, Y. Q., Chen, J. C., \& Ye, X. Q. (20II). Effect of three cooking methods on nutrient components and antioxidant capacities of bamboo shoot (Phyllostachys praecox C.D. Chu et C.S. Chao). Journal of Zhejiang University-SCIENCE B (Biomedicine \& Biotechnology), 12, 752-759. 


\section{FIGURES AND TABLES}

Table I. Free amino acids content $(\mathrm{mg} / \mathrm{l} 00 \mathrm{~g}$ fresh sample) in unsterilized (control), conventionally processed (retort sterilization) and ohmically processed (ohmic heating) vegetable baby purees

\begin{tabular}{lrrr}
\hline Aminoacids & Control & \multicolumn{1}{c}{ Retort } & \multicolumn{1}{c}{ Ohmic } \\
\hline Histidine (His) & $2.0 \pm 0.0^{\mathrm{c}}$ & $1.7 \pm 0.0^{\mathrm{b}}$ & $1.4 \pm 0.1^{\mathrm{a}}$ \\
Isoleucine (Ile) & $4.7 \pm 0.0^{\mathrm{b}}$ & $4.9 \pm 0.1^{\mathrm{b}}$ & $4.2 \pm 0.1^{\mathrm{a}}$ \\
Leucine (Leu) & $3.2 \pm 0.0^{\mathrm{b}}$ & $3.3 \pm 0.1^{\mathrm{b}}$ & $2.9 \pm 0.1^{\mathrm{a}}$ \\
Lysine (Lys) & $5.9 \pm 0.1^{\mathrm{b}}$ & $6.0 \pm 0.1^{\mathrm{b}}$ & $4.7 \pm 0.1^{\mathrm{a}}$ \\
Cysteine (Cys) & $0.2 \pm 0.0^{\mathrm{a}}$ & $0.2 \pm 0.0^{\mathrm{a}}$ & $0.2 \pm 0.0^{\mathrm{a}}$ \\
Methionine (Met) & $0.7 \pm 0.0^{\mathrm{a}}$ & $0.8 \pm 0.0^{\mathrm{a}}$ & $0.7 \pm 0.0^{\mathrm{a}}$ \\
Tyrosine (Tyr) & $2.5 \pm 0.1^{\mathrm{b}}$ & $2.6 \pm 0.0^{\mathrm{b}}$ & $1.8 \pm 0.3^{\mathrm{a}}$ \\
Phenylalanine (Phe) & $4.3 \pm 0.2^{\mathrm{c}}$ & $3.3 \pm 0.1^{\mathrm{b}}$ & $2.5 \pm 0.3^{\mathrm{a}}$ \\
Threonine (Thr) & $13.5 \pm 0.1^{\mathrm{b}}$ & $15.1 \pm 0.2^{\mathrm{c}}$ & $12.1 \pm 0.1^{\mathrm{a}}$ \\
Valine (Val) & $9.4 \pm 0.1^{\mathrm{b}}$ & $9.2 \pm 0.2^{\mathrm{b}}$ & $8.1 \pm 0.1^{\mathrm{a}}$ \\
Arginine (Arg) & $60.9 \pm 0.9^{\mathrm{c}}$ & $53.6 \pm 0.8^{\mathrm{b}}$ & $46.9 \pm 1.8^{\mathrm{a}}$ \\
Aspartic acid + asparagine (Asx) & $14.5 \pm 0.2^{\mathrm{b}}$ & $14.5 \pm 0.2^{\mathrm{b}}$ & $12.0 \pm 0.3^{\mathrm{a}}$ \\
Alanine (Ala) & $35.0 \pm 0.5^{\mathrm{b}}$ & $34.0 \pm 0.6^{\mathrm{b}}$ & $30.9 \pm 0.2^{\mathrm{a}}$ \\
Proline (Pro) & $2.8 \pm 0.4^{\mathrm{a}}$ & $2.8 \pm 0.4^{\mathrm{a}}$ & $2.8 \pm 0.4^{\mathrm{a}}$ \\
Glutamic acid + glutamine (Glx) & $27.6 \pm 0.7^{\mathrm{c}}$ & $25.1 \pm 0.7^{\mathrm{b}}$ & $20.6 \pm 0.3^{\mathrm{a}}$ \\
Serine (Ser) & $24.4 \pm 0.3^{\mathrm{c}}$ & $22.4 \pm 0.4^{\mathrm{b}}$ & $21.6 \pm 0.7^{\mathrm{a}}$ \\
Glycine (Gly) & $1.3 \pm 0.1^{\mathrm{a}}$ & $1.4 \pm 0.0^{\mathrm{a}}$ & $1.2 \pm 0.0^{\mathrm{a}}$ \\
Total free amino acids & $213 \pm 3^{\mathrm{c}}$ & $201 \pm 4^{\mathrm{b}}$ & $175 \pm 5^{\mathrm{a}}$ \\
Total sulphur amino acids & $0.9 \pm 0.0^{\mathrm{a}}$ & $1.0 \pm 0.0^{\mathrm{a}}$ & $0.8 \pm 0.0^{\mathrm{a}}$ \\
Total aromatic amino acids & $6.8 \pm 0.3^{\mathrm{c}}$ & $5.9 \pm 0.1^{\mathrm{b}}$ & $4.3 \pm 0.6^{\mathrm{a}}$ \\
\hline Vales
\end{tabular}

Values are mean $\pm S D(n=4)$. Different letters in a same row means significant differences 
Table 2. Total amino acids content ( $\mathrm{mg} / \mathrm{l} 00 \mathrm{~g}$ fresh sample) in unsterilized (control), conventionally processed (retort sterilization) and ohmically processed (ohmic heating) vegetable baby purees

\begin{tabular}{lrrr}
\hline Aminoacids & \multicolumn{1}{c}{ Control } & \multicolumn{1}{c}{ Retort } & \multicolumn{1}{c}{ Ohmic } \\
\hline Histidine (His) & $20.9 \pm 0.5^{\mathrm{b}}$ & $15.8 \pm 0.9^{\mathrm{a}}$ & $21.8 \pm 0.5^{\mathrm{b}}$ \\
Isoleucine (Ile) & $57.6 \pm 1.0^{\mathrm{b}}$ & $28.0 \pm 1.4^{\mathrm{a}}$ & $61.8 \pm 1.8^{\mathrm{b}}$ \\
Leucine (Leu) & $93.9 \pm 1.8^{\mathrm{b}}$ & $57.2 \pm 3.6^{\mathrm{a}}$ & $101.9 \pm 3.5^{\mathrm{c}}$ \\
Lysine (Lys) & $114.8 \pm 2.8^{\mathrm{b}}$ & $81.7 \pm 2.6^{\mathrm{a}}$ & $114.7 \pm 3.0^{\mathrm{b}}$ \\
Cysteine (Cys) & $1.2 \pm 0.7^{\mathrm{a}}$ & $1.3 \pm 0.3^{\mathrm{a}}$ & $1.0 \pm 0.1^{\mathrm{a}}$ \\
Methionine (Met) & $7.1 \pm 1.0^{\mathrm{b}}$ & $4.9 \pm 0.5^{\mathrm{a}}$ & $6.7 \pm 0.2^{\mathrm{b}}$ \\
Tyrosine (Tyr) & $4.4 \pm 0.4^{\mathrm{a}}$ & $3.6 \pm 0.5^{\mathrm{a}}$ & $4.9 \pm 1.0^{\mathrm{a}}$ \\
Phenylalanine (Phe) & $50.9 \pm 1.3^{\mathrm{b}}$ & $31.0 \pm 1.3^{\mathrm{a}}$ & $55.1 \pm 1.7^{\mathrm{b}}$ \\
Threonine (Thr) & $58.0 \pm 0.7^{\mathrm{b}}$ & $43.3 \pm 1.9^{\mathrm{a}}$ & $58.8 \pm 1.1^{\mathrm{b}}$ \\
Valine (Val) & $67.9 \pm 1.9^{\mathrm{b}}$ & $41.2 \pm 2.0^{\mathrm{a}}$ & $70.7 \pm 2.0^{\mathrm{b}}$ \\
Arginine (Arg) & $64.8 \pm 6.2^{\mathrm{b}}$ & $55.3 \pm 1.4^{\mathrm{a}}$ & $56.1 \pm 2.0^{\mathrm{a}}$ \\
Aspartic acid + asparagine (Asx) & $149.2 \pm 1.7^{\mathrm{b}}$ & $134.8 \pm 3.4^{\mathrm{a}}$ & $149.5 \pm 2.8^{\mathrm{b}}$ \\
Alanine (Ala) & $97.6 \pm 1.1^{\mathrm{a}}$ & $94.5 \pm 2.5^{\mathrm{a}}$ & $95.9 \pm 1.8^{\mathrm{a}}$ \\
Proline (Pro) & $46.7 \pm 2.3^{\mathrm{b}}$ & $40.9 \pm 2.2^{\mathrm{a}}$ & $48.9 \pm 1.6^{\mathrm{b}}$ \\
Glutamic acid + glutamine (Glx) & $239.3 \pm 4.0^{\mathrm{b}}$ & $215.8 \pm 4.4^{\mathrm{a}}$ & $230.0 \pm 3.9^{\mathrm{b}}$ \\
Serine (Ser) & $66.3 \pm 1.1^{\mathrm{b}}$ & $58.6 \pm 2.5^{\mathrm{a}}$ & $69.7 \pm 1.5^{\mathrm{b}}$ \\
Glycine (Gly) & $49.3 \pm 1.1^{\mathrm{b}}$ & $45.2 \pm 0.8^{\mathrm{a}}$ & $52.4 \pm 1.0^{\mathrm{b}}$ \\
Total amino acids & $1190 \pm 14^{\mathrm{b}}$ & $953 \pm 27^{\mathrm{a}}$ & $1200 \pm 23^{\mathrm{b}}$ \\
Total sulphur amino acids & $8.3 \pm 0.6^{\mathrm{b}}$ & $6.2 \pm 0.5^{\mathrm{a}}$ & $7.7 \pm 0.3^{\mathrm{b}}$ \\
Total aromatic amino acids & $55.3 \pm 1.4^{\mathrm{b}}$ & $34.6 \pm 1.8^{\mathrm{a}}$ & $60.0 \pm 0.8^{\mathrm{c}}$ \\
\hline
\end{tabular}

Values are mean $\pm S D(n=4)$. Different letters in a same row means significant differences 
Table 3. Amino acid score index and essential amino acids index (EAAI) of unsterilized (control), conventionally processed (retort sterilization) and ohmically processed (ohmic heating) vegetable baby purees according to FAO/WHO (20II) for different age groups

\begin{tabular}{|c|c|c|c|c|c|c|c|}
\hline \multirow[b]{2}{*}{ Samples } & \multirow[b]{2}{*}{ Amino acid } & \multicolumn{6}{|c|}{ Age (y) } \\
\hline & & 0.5 & $1-2$ & $3-10$ & $11-14$ & $15-18$ & $>18$ \\
\hline \multirow[t]{9}{*}{ Control } & His & 59 & 66 & 74 & 74 & 74 & 79 \\
\hline & Ile & 102 & 105 & 109 & 109 & 109 & 109 \\
\hline & Leu & 81 & 85 & 87 & 87 & 89 & 90 \\
\hline & Lys & 114 & 125 & 136 & 136 & 139 & 145 \\
\hline & Cys + Met & 18 & 19 & 21 & 21 & 21 & 22 \\
\hline & Tyr + Phe & 60 & 68 & 77 & 77 & 79 & 83 \\
\hline & Thr & 106 & 122 & 132 & 132 & 137 & 143 \\
\hline & Val & 90 & 94 & 96 & 96 & 96 & 99 \\
\hline & EAAI & 70 & 76 & 81 & 81 & 82 & 85 \\
\hline \multirow[t]{9}{*}{ Retort } & $\mathrm{His}$ & 43 & 48 & 54 & 54 & 54 & 58 \\
\hline & Ile & 48 & 50 & 51 & 51 & 51 & 51 \\
\hline & Leu & 48 & 50 & 51 & $5 I$ & 51 & 51 \\
\hline & Lys & 79 & 86 & 94 & 94 & 96 & 100 \\
\hline & Cys + Met & 13 & 14 & 15 & 15 & 15 & 15 \\
\hline & Tyr + Phe & 37 & 41 & 46 & 46 & 48 & 50 \\
\hline & Thr & 77 & 88 & 95 & 95 & 99 & 103 \\
\hline & Val & 53 & 55 & 57 & 57 & 57 & 58 \\
\hline & EAAI & 44 & 48 & 51 & 51 & 52 & 54 \\
\hline \multirow[t]{9}{*}{ Ohmic } & His & 60 & 66 & 75 & 75 & 75 & 80 \\
\hline & Ile & 105 & 109 & 113 & 113 & 113 & 113 \\
\hline & Leu & 84 & 88 & 91 & 91 & 93 & 94 \\
\hline & Lys & 110 & $12 \mid$ & $|3|$ & $|3|$ & 133 & 139 \\
\hline & Cys + Met & 16 & 17 & 18 & 18 & 18 & 19 \\
\hline & Tyr + Phe & 63 & 71 & 80 & 80 & 82 & 86 \\
\hline & Thr & 104 & 119 & 128 & 128 & 134 & 140 \\
\hline & Val & 90 & 94 & 97 & 97 & 97 & 99 \\
\hline & EAAI & 69 & 75 & 81 & 81 & 82 & 85 \\
\hline
\end{tabular}


Fig. I. Free (A) and total (B) amino acids content ( $\mathrm{mg} / \mathrm{l} 00 \mathrm{~g}$ fresh sample) in unsterilized (control), conventionally processed (retort sterilization) and ohmically processed (ohmic heating) vegetable baby purees grouped according to amino acid essentiality. Different letters mean significant differences among samples

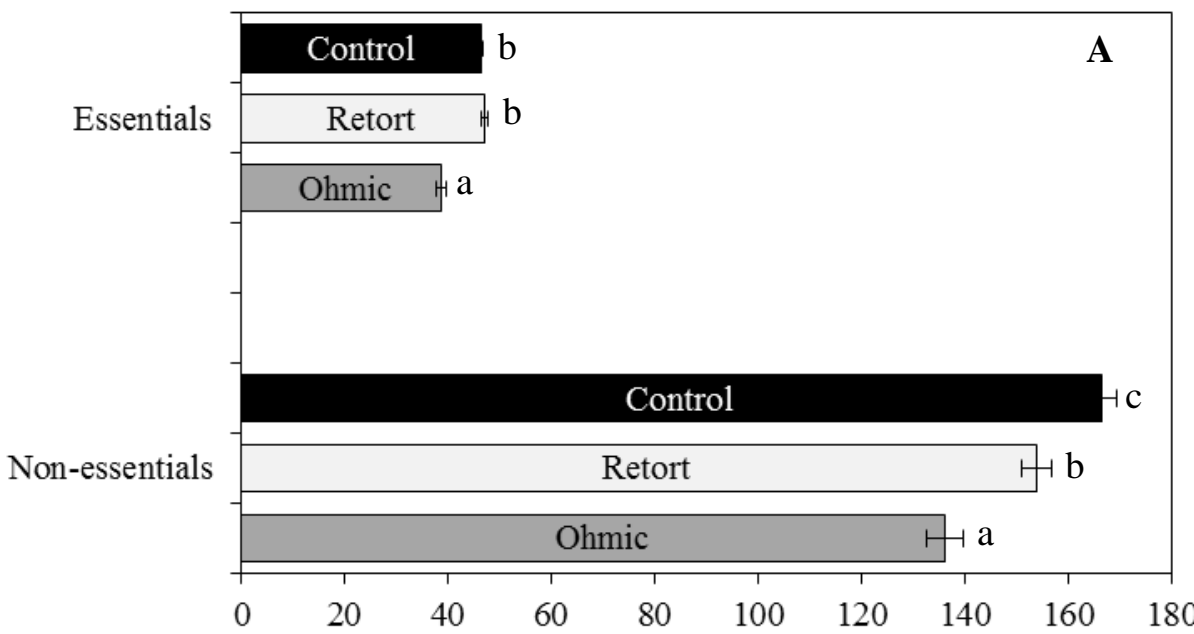

Free amino acids content $(\mathrm{mg} / 100 \mathrm{~g})$

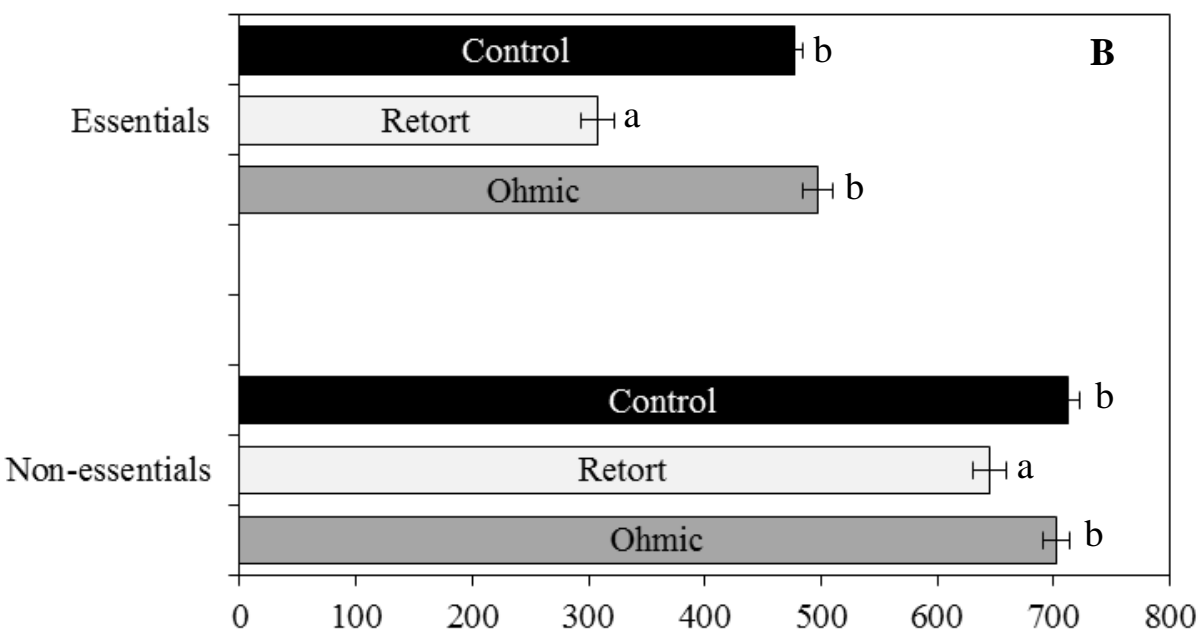

Total amino acids content $(\mathrm{mg} / 100 \mathrm{~g})$ 